\title{
Pengaruh Sertifikasi terhadap Kompetensi Sosial Guru SDN Se-Kecamatan Cikupa
}

\author{
Muhamad Rizki Riansyah Nurhasanudin ${ }^{1}$, Ainur Rosyid ${ }^{2}$ \\ 1,2Universitas Esa Unggul, Indonesia \\ E-mail: rizkiriansyah07@gmail.com,ainur.rosyid@esaunggul.ac.id
}

\section{Article Info \\ Article History \\ Received: 2021-12-27 \\ Revised: 2022-01-22 \\ Published: 2022-02-01}

Keywords:

Certification:

Teacher;

Competence.

\begin{abstract}
This study aims to determine and analyze the effect of teacher certification on social teachers at SDN in Cikupa District, Tangerang Regency. This research was conducted at an A-accredited school in Cikupa sub-district, this research was carried out in the odd semester of the 2020/2021 academic year, namely March, the research time with five stages of activity starting from the preliminary study in March until the last activity lasted to completion. The method that will be used is the questionnaire/survey method, the data obtained will then be processed and analyzed further to obtain conclusions, the analysis is carried out using a quantitative approach and for hypothesis testing is carried out by statistical methods. The results of this study indicate that it is important for social competence, this is related to the effect of certification on social competence $13.6 \%$ and the remaining $86.4 \%$ from the contribution of other variables not included in this study.
\end{abstract}

\begin{tabular}{|c|c|}
\hline Artikel Info & Abstrak \\
\hline $\begin{array}{l}\text { Sejarah Artikel } \\
\text { Diterima: } 2021-12-27 \\
\text { Direvisi: } 2022-01-22 \\
\text { Dipublikasi: } 2022-02-01\end{array}$ & $\begin{array}{l}\text { Penelitian ini bertujuan untuk mengenali serta menganalisis pengaruh sertifikasi guru } \\
\text { terhadap kompetensi sosial guru SDN Se-Kecamatan Cikupa Kabupaten Tangerang. } \\
\text { Penelitian ini dilakukan di Sekolah yang terakreditasi A di kecamatan Cikupa, } \\
\text { penelitian ini dilakukan pada semester ganjil tahun ajaran 2020/2021 yaitu bulan } \\
\text { Maret, waktu penelitian dijadwalkan dengan lima tahap kegiatan dimulai dari studi } \\
\text { pendahuluan pada bulan Maret sampai kegiatan terakhir berlangsung hingga selesai. } \\
\text { Metode yang akan digunakan ialah metode kuesioner/survey, data yang diperoleh } \\
\text { kemudian akan diolah dan dianalisis lebih lanjut untuk mendapatkan kesimpulan, } \\
\text { analisis dilakukan dengan menggunakan pendekatan kuantitatif dan untuk pengujian } \\
\text { hipotesis dilakukan dengan metode statistic, Hasil penelitian ini menunjukkan bahwa } \\
\text { sertifikasi berpengaruh terhadap kompetensi sosial, hal ini terkait pengaruh sertifikasi } \\
\text { terhadap kompetensi sosial sebesar } 13.6 \% \text { dan sedangkan sisanya } 86.4 \% \text { dari } \\
\text { konstribusi variabel lain yang tidak disertakan dalam penelitian ini. }\end{array}$ \\
\hline
\end{tabular}

\section{PENDAHULUAN}

Teknologi yang terus mengalami perkembangan berdampak besar dalam segala aspek terutama pendidikan, pendidikan adalah wadah untuk mencetak dan mengembangkan sumber daya manusia, inilah yang harus dilakukan pemerintah Indonesia agar meningkatkan fokus terhadap pendidikan supaya dapat benar-benar terjadi perubahan yang signifikan terhadap sumber daya manusia di Indonesia. Pendidikan adalah suatu sistem yang menggabungkan tiga bagian, input, proses dan output, dalam suatu sistem akan terjadi interaksi dan saling ketergantungan antara satu bagian dengan bagian lainnya. Input yang berkualitas akan berdampak pada kualitas proses dan pada akhirnya akan menghasilkan output yang berkualitas begitu juga sebaliknya. Namun dari ketiga bagian tersebut, bagian proses pembelajaran merupakan bagian yang sangat menentukan kondisi kualitas output dan kualitas input di masa mendatang. Proses pembelajaran terjadi dengan kerjasama dan dukungan guru, siswa, sarana prasarana, strategi dan lingkungan umum, pada bagian proses banyak pihak berpartisipasi secara langsung atau tidak langsung dan berbagi tanggung jawab. Guru, pemimpin, orang tua, staf, keamanan, tukang kebun dan lain-lain semua bertanggung jawab atas keberhasilan kelancaran dan kualitas proses pembelajaran, diantara orang-orang ini gurulah yang paling bertanggung jawab dalam proses pembelajaran. Guru merupakan sarana pendidikan yang paling penting dalam sistem pendidikan karena merupakan garda terdepan dalam penyelenggaraan pendidikan dan memiliki pengaruh yang signifikan dalam menciptakan proses pengajaran yang efektif dan hasil pendidikan yang berkualitas (Rosyid \& Marwan, n.d.). Kinerja guru dalam mengubah dan mengembangkan sikap keterampilan juga pengetahuan sangat diperlukan untuk proses mencerdaskan 
kehidupan dan mengubah taraf hidup masyaraxkat Indonesia.

Untuk mencapai tujuan tersebut tentunya diperlukan guru yang profesional dan kompeten dalam melaksanakan tugas yang diatur dalam Undang-Undang Republik Indonesia Nomor 14 Tahun 2005 tentang Guru dan Dosen, "Guru dinyatakan sebagai pendidik profesional yang tugas pokoknya mendidik melalui jalur pendidikan formal, pendidikan dasar dan menengah mengajar, menginstruksikan, melatih, menilai dan mengevaluasi peserta didik pada pendidikan anak usia dini"(No, 14 C.E.), gelar profesional dikenal sebagai pekerjaan yang membutuhkan standar kompetensi dan pendidikan profesional tertentu untuk menjadi sumber pendapatan hidup, selanjutnya pada tataran implementasi guru profesional ditandai dengan pemberian kredensial pendidik. Pada bulan januari 2021 saya berkesempatan untuk berbincang dengan beberapa guru SD di sekitar cikupa yaitu Ibu Lidia di SD Cordova Citra, dan Ibu Suci di SDIT Laa Tahzan Citra, memiliki latar belakang pendidikan yang serupa, dibidang keguruan, pada perbincangan yang saya lakukan saat ini guru sudah dalam situasi dimana harus bisa memanfaatkan alat komunikasi secara efektif, menciptakan komunikasi yang baik dengan orang tua siswa dan siswa dengan baik, dan memanfaatkan media pembelajaran yang efektif dalam proses pembelajaran, dalam percakapan saya dengan mereka, saya menge-tahui bahwasannya mereka sudah beberapa kali punya pengalaman mengajar di sekolah yang berbeda, dari pengalaman yang mereka punya dalam situasi saat ini (Pandeemi), kesulitan utama yang Ibu Suci alami yaitu siswa yang kurang mengerti materi dan orangtua yang belum bisa mendampingi siswa dengan mak-simal, sedangkan Ibu Lidia mengalami kesulitan dengan siswa yang mulai bosan dengan pelajaran, orangtua yang belum bisa menggunakan teknologi sebagai media pembe-lajaran dengan baik yang brdampak pada siswa menjadi malas dan guru tidak dapat mengetahui dengan baik bahwa siswanya benar-benar mengerti atau tidak.

Dari hasil perbincangan tersebut, dapat diketahui bahwa problematika yang dimiliki relative sama yaitu mengenai komunikasi yang belum efektif terhadap siswa dan orang tua siswa, hal ini dilihat dari siswa yang kurang bisa memahami materi dan keraguan dari guru yang belum bisa sepenuhnya mengetahui siswanya paham atau tidak, sebagaimana pernyataan saudara (Wisman, 2017) yaitu Dalam proses pembelajaran, komunikasi digunakan untuk menyampaikan informasi baik berupa ilmu pengetahuan maupun teknologi. Keberhasilan atau kegagalan pesan kepada siswa sangat tergantung pada efektivitas komunikasi, dan saudari (Lanani, 2013) mengatakan bahwa keberhasilan kegiatan pembelajaran sangat bergantung pada efektifitas proses komunikasi antara guru dan siswa yang terjadi dalam pembelajaran melalui interaksi edukatif. Melalui proses pembelajaran dan keterkaitannya dalam lingkungan pendidikan. Padahal sejatinya komunikasi adalah salah satu sub kompetensi dari kompetensi sosial yang harus dikuasai oleh setiap guru, namun dari perbincangan tersebut guru belum bisa menguasainya dengan baik.

Adapun beberapa penelitian yang mencerminkan bahwasannya kompetensi sosial adalah salah satu fokus utama yang harus dikuasai guru dengan baik, yaitu dari hasil penelitian saudara kurniawan, mengenai "dampak dari kebijakan sertifikasi guru terhadap profesionalitas guru Sekolah Dasar (SD) di Kota Yogyakarta", sebagian guru belum memliki jiwa profesionalitas kependidikan. Hal ini dapat dilihat dari salah satu hasil penelitiannya bahwa sikap guru yang acuh terhadap kualitas pengajaran, dan hanya berfokus pada peningkatan kesejahteraan, hal ini sangat disayangkan karena jika kualitas pembelajaran meningkat akan berdampak terhadap banyak sisi yang diantaranya adalah keberhasilan peserta didik dan peningkatan kualitas sekolah (Kurniawan, 2011), selain itu juga fakta lain disampaikan saudari saptarini dengan penelitian yang berjudul "Kekerasan Dalam Lembaga Pendidikan Formal (Studi Mengenai Kekerasan Oleh Guru Terhadap Siswa Sekolah Dasar di Surakarta)" bahwa kualitas guru yang tidak profesional yang terjadi di lembaga pendidikan khususnya sekolah dasar adalah akibat terjadinya tindak kekerasan. Hal ini terjadi karena belum adanya penanganan dan perhatian khusus diantara tenaga pendidik, tenaga pendidik yang belum bisa memisahkan masalah pribadinya yang akhirnya tindak kekerasan terjadi, hal ini masih diwajarkan di beberapa sekolah karena anggapan untuk mendisiplinkan murid yang akhirnya menjadi alasan untuk melakukan tindak kekerasan, padahal dampak dan kerugian yang dialami siswa tidak baik (Saptarini, 2009).

Jika memperhatikan penelitian diatas maka telah terjadi kesamaan antara penelitian yang satu dengan yang lainnya karena penelitian 
tersebut lebih menitik beratkan pada dampak dari sikap guru yang lebih mementingkan diri sendiri dan tidak bisa bersikap selayaknya profesi yang ditekuni, padahal sebagai seorang guru yang profesional guru harus dapat membagi dan menempatkan diri pada posisinya, hal inipun diperjelas dalam penelitian Saptarini bahwa tindak kekerasan yang dilakukan ter-hadap siapapun akan memberikan dampak yang negatif bagi pelaku tindak kekerasan. Hal tersebut sangat erat dengan efek yang diterima oleh oknum guru dengan adanya tindak keke-rasan yang dilakukannya yaitu berupa bentuk protes yang dilayangkan oleh orang tua siswa sebagai korban yang membuat anaknya menjadi trauma dengan guru tersebut, trauma dengan pelajaran bahkan membuat siswa menjadi tidak percaya diri, dan tidak hanya protes yang diterima oleh oknum guru, hilangnya keper-cayaan orang tua siswa terhadap guru dan sekolah menjadi pukulan keras bagi lembaga pendidik, karena tidak hanya kepercayaan namun kenyamanan dalam proses pendidikan akan terhambat, sehingga tujuan dari proses pendidikan tidak dapat terlaksana dengan baik (Saptarini, 2009), lembaga pemerhati anak yaitu KPAI mengeluarkan hasil dari pengawasan dan pengaduan mengenai tindak kekerasan di lembaga pendidikan, data tersebut dapat dilihat dalam bagan berikut:

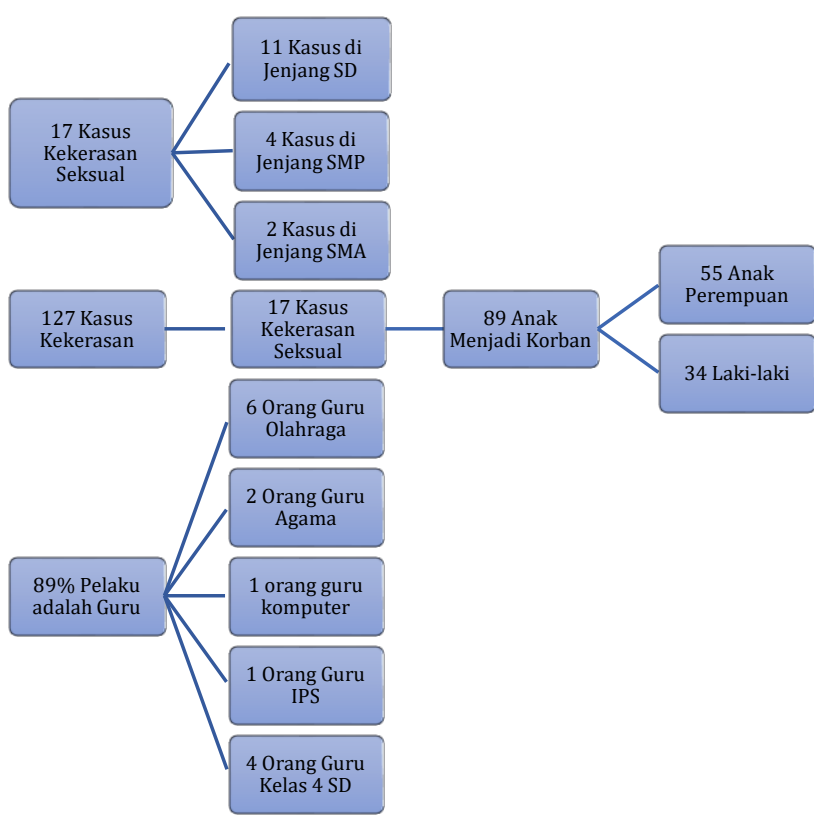

Gambar 1. Data Kasus Tindak Kekerasan di Lembaga Pendidikan Sejak Bulan JanuariOktober 2019
"Dari 17 kasus kekerasan seksual, 11 di SD, empat di SMP dan dua di SMA", kata Komisioner Pendidikan KPAI Retno Listyarti, Kantor KPAI, Selasa, 30 Oktober 2019 di Jakarta (https://nasional.tempo.co/read/1266367/kpaikekerasan-di-dunia-pendidikan-mencapai-127kasus) diakses pada tanggal 24 September 2020), dapat dipastikan dengan adanya kabar tersebut, sangat mencoreng dunia pendidikan khususnya lembaga pendidik yang notabene bertugas untuk mengawasi dan membina tenaga pendidik, hal ini membuat tingkat profesionalitas guru khususnya dalam kompetensi sosial patut untuk dipertanyakan. Indikator ini juga berlaku pada beberapa guru yang telah tersertifikasi nasional, sehubungan dengan rumusan permasalahan yang dikemukakan diatas hingga tujuan riset ini untuk mengenali serta menganalisis pengaruh sertifikasi guru terhadap kompetensi sosial guru SDN Se-Kecamatan Cikupa Kabupaten Tangerang.

\section{METODE PENELITIAN}

Penelitian ini dilakukan di Sekolah yang terakreditasi A di kecamatan Cikupa, penelitian ini dilakukan pada semester ganjil tahun ajaran 2020/2021 yaitu bulan Maret, waktu penelitian dijadwalkan dengan lima tahap kegiatan dimulai dari studi pendahuluan pada bulan Maret sampai kegiatan terakhir berlangsung hingga selesai. Metode yang akan digunakan ialah metode kuesioner/survey, data yang diperoleh kemudian akan diolah dan dianalisis lebih lanjut untuk mendapatkan kesimpulan, analisis dilakukan dengan menggunakan pendekatan kuantitatif dan untuk pengujian hipotesis dilakukan dengan metode statistik. Populasi adalah seluruh subjek data yang akan diteliti (Arikunto, 2019, p. 108). Populasinya adalah Guru yang sudah bersertifikat yang mengajar di SDN terakreditasi A di Kecamatan Cikupa, yang berjumlah 70 orang. Sampel adalah bagian dari total populasi (Sugiyono, 2017a, p. 81), teknik pengambilan sampel memakai nonprobability sampling dengan jenis purposive sampling, sampel penelitian ini sebanyak 36 guru tersebar di 4 sekolah yaitu SDN Bojong 1, SDN Cikupa 02, SDN Cikupa 03, dan SDN Talagasari. Variabel yang diteliti adalah pengaruh sertifikasi guru selaku variabel $\mathrm{X}$ bebas (Inde-pendent) dan kompetensi sosial selaku variabel Y terikat (Dependent).

Metode yang digunakan dalam penelitian ini adalah metode kuantitatif, secara umum metode kuantitatif lebih fokus pada tujuan generalisasi melalui uji statistik dan metode steril yang tidak tunduk pada pengaruh subjektif peneliti, dalam 
penelitian ini akan dianalisis mengenai Pengaruh Sertifikasi terhadap Kompetensi Sosial Guru SDN Se-Kecamatan Cikupa Kabupaten Tangerang.

\section{HASIL DAN PEMBAHASAN}

\section{A. Hasil Penelitian}

1. Uji Korelasi

Analisis korelasi menggunakan rumus pearson product moment dengan berbantuan program SPSS 22 for windows.

Tabel 1. Uji Korelasi

\section{Correlations}

\begin{tabular}{llcr}
\hline \multicolumn{1}{c}{ Model } & Sertifikasi & \multicolumn{2}{c}{$\begin{array}{c}\text { Kompetensi } \\
\text { Sosial }\end{array}$} \\
\hline \multirow{4}{*}{ Sertifikasi } & Pearson & 1 & $.368^{*}$ \\
& $\begin{array}{l}\text { Correlation } \\
\text { Sig. (2-tailed) }\end{array}$ & & .027 \\
& N & 36 & 36 \\
Kompetensi & Pearson & $.368^{*}$ & 1 \\
Sosial & Correlation & & \\
& Sig. (2-tailed) & .027 & 36 \\
\hline *Correlation is significant at the 0.05 level (2-tailed). &
\end{tabular}

Berdasarkan data diatas menunjukkan bahwa masing-masing variabel memiliki nilai signifikansi adalah 0,000 , sehingga $0,027<0,05$ maka artinya berkorelasi, untuk nilai pearson correlation masingmasing variabel adalah 0.368 jika dilihat dalam pedoman hubungan memiliki nilai korelasi kuat.

\section{Uji Koefisien Determinasi}

Uji koefisien determinasi dihitung dengan bantuan program SPSS 22 for windows.

Tabel 2. Uji Koefisien Determinasi

\section{Model Summaryb}

\begin{tabular}{llrrr}
\hline Model & R & $\begin{array}{c}\text { R } \\
\text { Square }\end{array}$ & $\begin{array}{c}\text { Adjusted R } \\
\text { Square }\end{array}$ & $\begin{array}{r}\text { Std. Error of } \\
\text { the Estimate }\end{array}$ \\
\hline 1 & $.368^{\mathrm{a}}$ & .136 & .110 & 9.008 \\
\hline
\end{tabular}

a) Predictors: (Constant), $X$

b) Dependent Variable: $Y$

\section{Uji-t}

Uji hipotesis ini menggunakan uji-t berbantuan program SPSS 22 for windows, data hasil perhitungan selanjutnya dilakukan perbandingan pada tabel dengan menentukan tingkat kesalahan 0,05 dengan kriteria sebagai berikut:

a) $\mathrm{H}_{0}$ ditolak jika nilai thitung $\leq$ ttabel atau nilai sig $>\alpha$

b) $\mathrm{H}_{1}$ diterima jika nilai thitung $\geq$ ttabel atau nilai sig $<\alpha$
Tabel 3. Uji-t

Coefficients ${ }^{a}$

\begin{tabular}{lrrrrrr}
\hline Model & \multicolumn{2}{c}{$\begin{array}{c}\text { Unstandardized } \\
\text { Coefficients }\end{array}$} & $\begin{array}{c}\text { Standardized } \\
\text { Coefficients } \\
\text { Std. }\end{array}$ & Beta & T & Sig. \\
& B & Error & & & \\
\hline \multirow{2}{*}{$\begin{array}{l}\text { (Constant) } \\
\text { X }\end{array}$} & 50.337 & 23.534 & & 2.139 & .040 \\
\hline a) $\quad$ Dependent Variable: $Y$ & .448 & .194 & .368 & 2.311 & .027 \\
\hline
\end{tabular}

Dapat dijelaskan dalam tabel diatas diperoleh nilai signifikansi adalah 0,027 dan $t_{\text {hitung }}$ adalah 2.311 , maka $0,027<0,05$ dan apabila dibandingan dengan $t_{\text {tabel }}$ nilai $2.311 \geq 1.68830$, dan bila dilihat pada kriteria tersebut artinya $\mathrm{H}_{1}$ diterima. Maka dapat disimpulkan bahwa $\mathrm{H}_{1}$ diterima artinya sertifikasi guru berpengaruh terhadap kompetensi sosial guru SDN SeKecamatan Cikupa.

4. Analisis Regresi Sederhana

Analisis regresi linier sederhana digunakan untuk menguji pengaruh satu variabel bebas $(\mathrm{X})$ terhadap variabel terkait $(\mathrm{Y})$. Hal ini dapat dilihat pada tabel berikut yang dibantu dengan menggunakan aplikasi SPSS 22.

Tabel 4. Model Summary

Model Summary

\begin{tabular}{|c|c|c|c|c|}
\hline Model & $\mathbf{R}$ & R Square & $\begin{array}{l}\text { Adjusted R } \\
\text { Square }\end{array}$ & $\begin{array}{l}\text { Std. Error of } \\
\text { the Estimate }\end{array}$ \\
\hline 1 & ,368 & ,136 & ,110 & 9,008 \\
\hline
\end{tabular}

Tabel diatas menjelaskan besarnya nilai korelasi/hubungan (R) yaitu sebesar 0,368 , dari output tersebut diperoleh koefisien determinasi ( $\mathrm{R}$ Square) sebesar 0,136, yang mengandung pengertian bahwa pengaruh variabel bebas (Sertifikasi) terhadap variabel terikat (Kompetensi Sosial) adalah sebesar $13,6 \%$.

Tabel 5. Coefficient

Coefficients $^{\mathbf{a}}$

\begin{tabular}{|c|c|c|c|c|c|c|}
\hline \multirow{2}{*}{\multicolumn{2}{|c|}{ Model }} & \multicolumn{2}{|c|}{$\begin{array}{c}\text { Unstandardized } \\
\text { Coefficients }\end{array}$} & \multirow{2}{*}{$\begin{array}{c}\begin{array}{c}\text { Standardized } \\
\text { Coefficients }\end{array} \\
\text { Beta } \\
\end{array}$} & \multirow{2}{*}{$\mathbf{t}$} & \multirow{2}{*}{ Sig. } \\
\hline & & B & $\begin{array}{l}\text { Std. } \\
\text { Error }\end{array}$ & & & \\
\hline \multirow[t]{2}{*}{1} & (Constant) & 50,337 & 23,534 & & 2,139 & ,040 \\
\hline & Sertifikasi & ,448 & 194 & ,368 & 2,311 & ,027 \\
\hline
\end{tabular}

Diketahui nilai konstan (a) sebesar 50,377 sedangkan nilai Sertifikasi (b/koefesien regresi) sebesar 0,448 sehingga persamaan regresinya dapat ditulis:

$$
\mathrm{Y}=\mathrm{a}+\mathrm{bX}
$$




$$
\mathrm{Y}=50,337+0,448 \mathrm{X}
$$

Persamaan tersebut dapat diterjemahkan sebagai berikut, yaitu kostanta sebesar 50,337 mengandung arti bahwa nilai koefisien variabel Kompetensi Sosial sebesar 50,337, koefisien regresi X sebesar 0,448 menyatakan bahwa setiap penambahan $1 \%$ nilai Sertifikasi, maka nilai Kompetensi Sosial bertambah sebesar 0,448 . Koefisien regresi tersebut bernilai positif, sehingga dapat dikatakan bahwa arah pengaruh variabel $\mathrm{X}$ terhadap $\mathrm{Y}$ adalah Positif.

\section{B. Pembahasan}

Untuk bagian pembahasan hasil penelitian bisa dijabarkan temuan yang didapatkan dari hasil analisis data pada penelitian mengenai Pengaruh Sertifikasi terhadap Kompetensi Sosial Guru SDN se-Kecamatan Cikupa, penjelasan berikut pada dasarnya menggambarkan perilaku sosial yang dimiliki oleh guru yang telah tersertifikasi. Hasil yang ditemukan setelah mengolah data yang didapat menunjukkan bahwa sertifikasi memiliki pegaruh yang sangat baik terhadap kompetensi sosial dengan angka presentasi sebesar 89,65\%. Kemudian kompetensi sosial dapat dikategorikan baik dengan angka presentasi sebesar 77,49\%. Penelitian ini didukung oleh penelitian dari (Kasmianti \& Fikri, 2015) yang menyatakan bahwa sertifikasi memiliki pengaruh yang baik terhadap kompetensi sosial guru, sertifikasi dapat dikategorikan dengan sangat baik dapat dilihat dari hasil survey tiap indicator yang berupa melindungi profesi guru dari praktikpraktik janggal yang dapat merugikan wajah dari profesi pendidik sebesar 87,78\%, mlindungi masyarakat pada umumnya dari praktik instruktif yang tidak layak dan cakap sebesar $89,72 \%$, menjadi wahana pengukuhan mutu bagi Lembaga Penyelenggara Pendidik dan Tenaga Kependidikan (LPTK) dan pengendalian mutu dan jumlah pendidik untuk klien administrasi sekolah sebesar 90\%, mempertahankan lembaga pendidikan dari keinginan internal dan ketegangan luar yang menyimpang dari pedoman yang relevan $89,07 \%$ mendapatkan tunjangan profesional untuk pendidik yang lulus ujian sertfikasi sebesar 90,37\%.

Kompetensi sosial dapat dikategorikan dengan baik dapat dilihat dari hasil survey tiap indicator yang berupa menyampaikan secara lisan dan tertulis, atau berpotensi memberi isyarat dengan cara yang dapat diterima sebesar 91\%, menggunakan teknologi komunikasi dan informasi secara praktis sebesar 91\%, berbaur secara aktif dengan siswa, instruktur individu, staf sekolah, perintis unit pelatihan, wali atau penjaga siswa sebesar $91,67 \%$, bermitra secara santun dengan lingkungan sekitar dengan memperhatikan standar umum dan kerangka nilai sebesar 91,78\%, menerapkan standar persaudaraan sejati dan jiwa kebersamaan $89,17 \%$. Hal ini berbeda dengan penelitian (Kasmianti \& Fikri, 2015) yang menyatakan bahwa kompetensi sosial guru yang telah tersertifikasi kurang baik dikarenakan sibuk dengan pekerjaannya sendiri.

\section{SIMPULAN DAN SARAN}

\section{A. Simpulan}

Berdasarkan data yang telah dianalisis, dapat disimpulkan bahwa sertifikasi berpenga-ruh terhadap kompetensi sosial. Hal ini terkait pengaruh sertifikasi terhadap kompetensi sosial sebesar $13.6 \%$ dan sedangkan sisanya $86.4 \%$ dari konstribusi variabel lain yang tidak disertakan dalam penelitian ini.

\section{B. Saran}

Berdasarkan hasil pembahasan dan simpulan, penulis memberikan saran sebagai berikut.

1) Bagi guru untuk terus meningkatkan kualitas kompetensi sosial agar dapat menciptakan kondisi yang nyaman dalam proses pembelajaran dan berinteraksi dalam lingkup sekolah maupun diluar sekolah.

2) Bagi peneliti selanjutnya, penelitian ini dapat dilakukan kembali menggunakan objek yang berbeda dan penelitian ini dapat dipakai sebagai rujukan dalam penelitian terkait dengan sertifikasi dan kompetensi sosial.

\section{DAFTAR RUJUKAN}

Arikunto, S. (2019). Prosedur Penelitian Suatu Pendekatan Praktik. IV.

Halim, A. (2020). Manajemen Marketing Pendidikan Islam. Al-Ibrah, 5(1), 1-26.

Kasmianti, R., \& Fikri, H. (2015). PENGARUH SERTIFIKASI TERHADAP KOMPETENSI SOSIAL GURU BAHASA INDONESIA SMP DI 


\section{KECAMATAN KOTO XI TARUSAN KABUPATEN PESISIR SELATAN. JURNAL FAKULTAS KEGURUAN DAN ILMU PENDIDIKAN, 4(2).}

Kurniawan, B. D. (2011). Implementasi Kebijakan Sertifikasi Guru Dalam Rangka Meningkatkan Profesionalitas Guru Di Kota Yogyakarta. Journal of Government and Politics, 2(2), 259-278. https://doi.org/10.18196/jgp.2011.0015

Lanani, K. (2013). Belajar berkomunikasi dan komunikasi untuk belajar dalam pembelajaran matematika. Infinity Journal, 2(1), 13-25.

Manurung, A. S., Halim, A., \& Rosyid, A. (2020). Pengaruh Kemampuan Berpikir Kreatif untuk meningkatkan Hasil Belajar Matematika di Sekolah Dasar. Jurnal Basicedu, 4(4), 1274-1290.
No, U.-U. R. I. (14 C.E.). tahun 2005 tentang Guru dan Dosen.

Rosyid, A., \& Marwan, R. H. (n.d.). UPAYA GURU SEKOLAH DASAR NON KEPENDIDIKAN DALAM MENGEMBANGKAN KOMPETENSI PEDAGOGIK.

Saptarini, Y. (2009). Kekerasan dalam lembaga pendidikan formal (studi mengenai kekerasan oleh guru terhadap siswa sekolah dasar di Surakarta).

Sugiyono. (2017a). Metode Penelitian Kuantitatif, Kualitatif, dan $R \& D$. Alfabeta.

Wisman, Y. (2017). Komunikasi efektif dalam dunia pendidikan. Jurnal Nomosleca, 3(2). 